\title{
THE ANALYSIS OF TOPICS AND TOPIC BOUNDARY MARKERS IN IONESCO'S ABSURD PLAY THE LESSON
}

\author{
Henny Putri Saking Wijaya \\ Fakultas Sastra, Universitas Kristen Petra, Surabaya, Indonesia \\ Email: hennypsw@petra.ac.id
}

\begin{abstract}
People sometimes experience miscommunication when they have a conversation. It may happen because they fail to recognize the topic of discussion and the topic shift markers. A conversation has a clear structure that is not realized by the speakers. In this study, the writer chose The Lesson, one of the most famous absurd plays by Ionesco, as the data. In this play, the structure of conversation is difficult to understand, especially in the conversation between the Professor and the Young Pupil. Based on this condition, the writer investigates the structure of the conversation between the Professor and the Young Pupil in order to find the main topics and the topic boundary markers occurred in the topic shift in the conversation. The data were analyzed using the theories of topic shift by Coulthard (2014) and topic boundary markers by Stenstrom (2014). The findings show that there were four topics in the conversations between the Professor and the Young Pupil and 'let's' is the topic boundary marker often used to open a new topic and to close a topic. In conclusion, even in an absurd play where the structure is difficult to understand, there is a clear structure of the conversation.
\end{abstract}

Keywords: topic; topic boundary marker; absurd play

\section{Introduction}

People do conversations in their everyday life. According to Stenstrom, conversation is a "social activity involving two or more participants who talk about something" (2014, p.189). It means that at least two individuals are taking part as the speaker and the listener. Furthermore, each of participants has power to control the ongoing conversation, in relation to the position of the participants. For instance, when a teacher has a conversation with his/her student, in many cases the teacher will have more power to control the conversation.

People can have normal conversations in their daily interactions.
Normal conversations can also happen in plays. However, in plays, there are conversations that make the topics of discussion cannot be seen clearly, for example, in absurd plays. In the Collins Dictionary, theatre of the absurd is defined "drama in which normal conventions and dramatic structure are ignored or modified in order to present life as irrational or meaningless." In this kind of literature, the absurdity of human life is represented clearly. In absurd plays, the structures of the conversation are difficult to understand because the order is not as simple as in normal conversations. It makes absurd plays very unique and interesting to analyze. 
Eugene Ionesco is regarded as the Absurdist because he is "the author of hilarious nonsense plays" (Esslin, 2001, p.133). One of his famous absurd plays is The Lesson. Esslin (p.146) states "there is more about language in The Lesson than a demonstration of the difficulties of communication. Here language is also shown as an instrument of power." Even though the language used in the play is simple, the structure of successive utterances, which is difficult to understand, has interested the writer to analyze further. There are two research questions that the writer wants to answer: 1) What are the main topics occurred in the conversation? 2) What are the topic boundary markers occurred in the topic shift in the conversation?

In order to be able to take part in a conversation, people need to know about the topic being discussed. Topic is a part of interesting conversations. According to McCarthy, topics "are the strings of utterances perceived as relevant to one another by participants in talk" (1991, p.132). One topic can consist of many related sub-topics. Moreover, it is common in a conversation that one of the participants proposes a topic. Each participant has the equal right to contribute a topic. Topic in a conversation is not fixed but it is negotiated in the process of conversation (Brown and Yule, 1983, p.89). It means that some topics proposed by the participants will be accepted as the topic of conversation and some others will be rejected. In a conversation, the participants not only talk about one topic but also shift and develop the topic. When a participant responds to a topic and then proposes a new topic, topic shift occurs in the conversation.

Topic shift is the point at which the participants of a conversation move from the current topic into the new topic. Sacks (1971 cited in Coulthard, 2014, p.80), "observes that in a conversation which is progressing well talk drifts imperceptibly from one topic to another, and suggests that the relative frequency of marked topic introduction is some measure of the quality of a conversation." It means that the occurrence of topic shift in a conversation is important because it can make the ongoing conversation run smoothly.

Topic shift is very important especially in keeping the conversation still going on and 
avoiding silences (McCarthy, 1991, p.134). Topic shift is an important skill. People need topic shifts to make coherent utterances so that they may be able to give the right comment or response in an appropriate time. They have to know the markers in order to make a clear shift from one topic to another. The examples of shift markers are by the way, that reminds me of, well, speaking about, actually, all right, or even short silence. By knowing these remarks, the participants of a conversation will be able to recognize the changing of the topic easily. The following is the example of topic shift (Stenstrom, 2014, p.156):

1 A: ... I'm sure he went for a smoke.

2 B: I did know one Indian who ironically learnt to chainsmoke in this country

$3 \mathrm{~A}$ : ... he could break it in holidays but as soon as the term began again. The strain was too much. Couldn't go and do without them any longer.

\section{$4 \mathrm{~B}$ : What part of India were you in?}

The extract above shows that there is a topic change. In line 1-3, A and B are talking about their Indian colleague. Then in line 4, B changes the topic of discussion to A's experience in India.

In order to understand the structure of a conversation, the writer needs to identify the topic boundary markers. These markers are used to give a sign where one unit ends and another begins. They are used to point out whether a topic has changed or not, and are needed to connect one utterance to another in a language in order to make a coherent sentence (Brown and Yule, 1983, pp.94-95). Moreover, topic shift markers are very important because the failure in marking the shift of the topic can cause misinterpretation of the message that the speaker wants to convey. The following is the example of topic boundary marker (Stenstrom, 2014, p.158):

(A and B have been talking about domestic matters when B suddenly remembers that she has promised to deliver a message)

"Ok. And by the way, I forgot to tell you last night that Bill Potterton wants us to go round on Sunday afternoon."

In the example above, B gives a sign 'by the way' as the opening marker before she changes the topic of discussion.

There are some studies related to topic shift and topic shift markers; however, most of them did not analyze plays, especially absurd plays. One of them is the study conducted by Wulandari (2001). The subjects were male and female students who were chatting in the boarding house. Another study related to topics which 
analyzed a play was done Jones (2008). He analyzed Absurd Person Singular by Alan Ayckbourn. Thus, analyzing topics and topic boundary markers in absurd plays is interesting to discuss.

\section{Research Method}

This research was conducted by using the qualitative approach in which the source of data was from a literary work of Ionesco entitled The Lesson. As the data of the research, the writer took the conversation between the Professor and the Young Pupil because both of them are the main characters who do most of the conversation. The writer rewrote the conversation between the Professor and the Young Pupil because she adjusted with the table that she used in the data analysis.

The analysis began with the categorization of the conversation by using the following table 1:

Table 1. Topics and Sub-topics of the Conversation

\begin{tabular}{c|c|c|c}
$\begin{array}{c}\text { Dialog } \\
\text { line }\end{array}$ & Dialog & $\begin{array}{c}\text { Main } \\
\text { Topic }\end{array}$ & $\begin{array}{c}\text { Sub } \\
\text { Topic }\end{array}$ \\
\hline & & & \\
\hline & & &
\end{tabular}

The writer put the conversation that has been rewritten in the table. Then, the topic boundary markers that gave clear markers where one topic ends and another topic begins were analyzed. The markers were put into a table 2 :

Table 2. Topic Boundary Markers

\begin{tabular}{l|c|c|c} 
No & $\begin{array}{c}\text { Opening } \\
\text { Marker }\end{array}$ & $\begin{array}{c}\text { Closing } \\
\text { Marker }\end{array}$ & $\begin{array}{c}\text { Opening }+ \\
\text { Closing } \\
\text { Markers }\end{array}$ \\
& & & \\
\hline & & & \\
& & &
\end{tabular}

Next, the writer divided the conversations into small units by using the topic boundary markers. It is needed in order to determine the main topics and the sub topics of the conversations.

\section{Findings and Discussion}

The findings show that there were four topics with several sub topics in the conversation between the Professor and the Young Pupil. Moreover, the topic boundary markers in the topic shift could be identified in the conversation. The discussion is divided into main topics and topic boundary markers. 


\subsection{Main topics}

From the analysis, the writer found that the topics of conversation between the Professor and the Young Pupil could be categorized into four namely Introduction, Arithmetic, Linguistics and Comparative Philology, and Closing. However, the closing was drawn in dots because the conversation that occurs is between the Professor and the Maid and this was not analyzed. See the diagram 1

Diagram 1. Main Topics
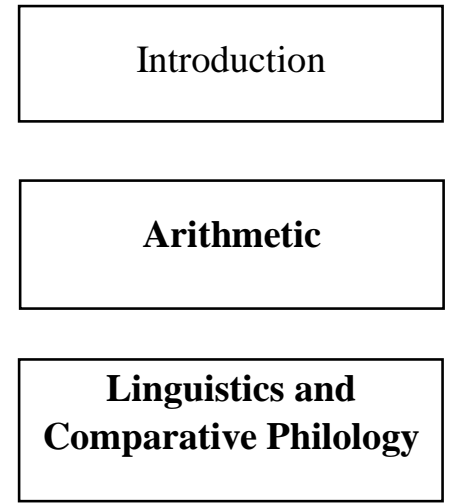

Closing

The diagram shows that there are two main topics of the conversation: Arithmetic, and Linguistics and Comparative Philology. Those main topics are the lessons given by the Professor to the Young Pupil. The findings of the main topics were related to the topic boundary markers. The writer used these topic boundary markers to help her to determine the main topics because these markers were the signs where one topic ends and another topic begins. In order to show the main topics, the writer provides some extracts of each. Extract 1 shows that the first main topic namely 'arithmetic'.

Extract 1:

(53) $P$ : If you will ... now ... we ... we ... I ... I will begin by making a brief examination of your knowledge, past and present, so that we may chart our future course ... Good. How is your perception of plurality?

(54) $Y$ : It's rather vague ... confused.

(55) $P$ : Good. We shall see.

(56) $P$ : Now, miss, would you like to do a little arithmetic, that is if you want to ...

(57) $Y \quad:$ Oh, yes, Professor. Certainly, I ask nothing better.

(58) $P \quad$ :It is rather a new science, a modern science, properly speaking, it is more a method than a science ... And it is also a therapy. Have you finished, Marie?

(The Maid interrupts the conversation between the Professor and the Young Pupil)

(59) $P$ : Miss, I hope you'll pardon this absurd interruption ... Excuse this woman ... She is always afraid that I'll tire myself. She fusses over my health.

(60) $Y:$ Oh, that's quite all right, Professor. It shows that she's very devoted. She loves you very much. Good servants are rare. 
(61) $P$ : She exaggerates. Her fears are stupid. But let's return to our arithmetical knitting.

(62) $Y \quad$ : I'm following you, Professor.

From the extract above, the Professor says 'now' and 'I will begin' in line 53 as the signs to show that the Professor wants to start the lesson. Those signs are the topic boundary marker used to show the beginning of a topic. In line 56, it can be seen that the Professor asks the Young Pupil to learn arithmetic when he asks "would you like to do a little arithmetic?" This request is the marker showing the first main topic of the conversation: arithmetic. Then, there is an interruption by the maid. It makes the Professor talk about another topic. When he remembers to continue talking about 'arithmetic', he gives a marker 'but let's return' (line 61).

The following Extract shows the second main topic namely 'Linguistics and Comparative Philology'.

Extract 2:

(206)P : Let's leave it for the moment. Let's go on to another exercise ...

(207) Y : Yes, Professor.

(208)P : It is unfortunate, miss, that you aren't further along in specialized mathematics ...
(209)P : I hear that you will not be able to qualify for the total doctor's orals ...

(210) Y : Yes, Professor, it's too bad!

(211)P : Unless you ... (Let me be, Marie ... Look here, why are you bothering me? Go back to the kitchen! To your pots and pans! Go away! Go away!) We will try to prepare you at least for the partial doctorate...

(212)P : (Now leave me alone! Let me be! What's the meaning of this?) I must therefore teach you, if you really do insist on attempting the partial doctorate ...

(213) Y : Yes, Professor.

(214) $P \quad \therefore$... The elements of linguistics and of comparative philology

(The Maid interrupts the conversation between the Professor and the Young Pupil)

(215)P : Let's continue, miss.

(216)Y : Yes, Professor.

(217)P : I want you to listen now with the greatest possible attention to a lecture I have prepared

(218) Y : Yes, Professor.

(219)P : ... Thanks to which, in fifteen minutes' time, you will be able to acquire the fundamental principles of the linguistic and comparative philology of the neo-Spanish languages.

(220) Y : Yes, Professor, oh good!

Extract 2 above shows that the Professor wants to stop the arithmetic 
lesson when he says "Let's leave it for a moment" in line 206. The word "it" in the marker refers to arithmetic. Then, he wants to teach his pupil another lesson when saying "Let's go on to another exercise" in line 206. Thus, 'let's leave it' is the topic boundary marker used to give a sign where the first main topic ends and 'let's go on to' is the marker to give a sign where the second main topic begins. The Professor does not mention directly what kind of exercise that the Pupil will have in line 206. He finally states clearly the next lesson in line 214 when he mentions 'the elements of Linguistics and Comparative Philology'.

The introduction and each main topic were composed of sub topics and sub-sub topics. The sub topics and sub-sub topics were classified after identifying the topic boundary markers in each unit. The details of the introduction and each main topic can be seen in Image 1 .
Image 1: The details of the introduction and each main topic

\begin{tabular}{|c|c|}
\hline $\begin{array}{l}\text { Introduction: } \\
\text { - } \quad \text { Finding the house } \\
\text { - Knowledge about Paris } \\
\text { - } \quad \text { Weather/climate } \\
\text { - Season } \\
\text { - Specialization } \\
\text { - } \quad \text { School qualification } \\
\text { Preparation of the course }\end{array}$ & $\begin{array}{l}\text { sub topic } \\
\text { sub topic } \\
\text { sub topic } \\
\text { sub-sub topic } \\
\text { sub topic } \\
\text { sub-sub topic } \\
\text { sub topic }\end{array}$ \\
\hline 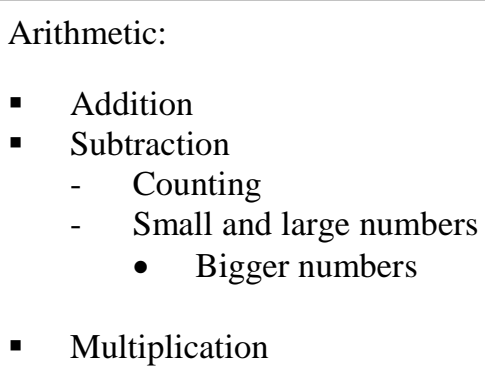 & $\begin{array}{l}\text { sub topic } \\
\text { sub topic } \\
\text { sub-sub topic } \\
\text { sub-sub topic } \\
\text { sub-sub-sub } \\
\text { topic } \\
\text { sub topic }\end{array}$ \\
\hline $\begin{array}{l}\text { Linguistics and Comparative Phild } \\
\text { - Neo-Spanish } \\
\text { - Phonology } \\
\text { - } \quad \text { Affixes } \\
\text { - Word structure } \\
\text { - Differences of diverse } \\
\quad \text { language }\end{array}$ & $\begin{array}{l}\text { logy: } \\
\text { sub topic } \\
\text { sub topic } \\
\text { sub topic } \\
\text { sub topic } \\
\text { sub-sub topic }\end{array}$ \\
\hline
\end{tabular}

\section{a. Topic boundary markers}

The findings show that the topic boundary markers in the conversation can be divided into three categories namely Opening, Closing, and Opening and Closing. In general, 'let's' is the topic boundary marker often used to open a new topic and to close a topic. Besides 'let's', the characters also often use questions as the markers. Table 3 shows the topic boundary markers used in the conversation. 
Table 3. Topic Boundary Markers

\begin{tabular}{|c|c|c|c|}
\hline Line & Opening & Closing & $\begin{array}{c}\text { Opening } \\
+ \\
\text { Closing }\end{array}$ \\
\hline 5 & $\begin{array}{l}\text { Please } \\
\text { excuse } \\
\text { me... Did } \\
\text { you have } \\
\text { any trouble } \\
\text { finding the } \\
\text { house? }\end{array}$ & & \\
\hline 10 & $\begin{array}{l}\text { Do you like } \\
\text { Bourdeaux? }\end{array}$ & & \\
\hline 17 & $\begin{array}{l}\text { What a nice } \\
\text { day it is } \\
\text { today... }\end{array}$ & & \\
\hline 22 & $\begin{array}{l}\text { The snow } \\
\text { falls in the } \\
\text { winter. }\end{array}$ & & \\
\hline 32 & & $\begin{array}{l}\text { Oh, I do } \\
\text { hope so, } \\
\text { Professor. }\end{array}$ & \\
\hline 32 & $\begin{array}{l}\text { I have a } \\
\text { great thirst } \\
\text { for } \\
\text { knowledge. }\end{array}$ & & \\
\hline 35 & $\begin{array}{l}\text { And you } \\
\text { wish to } \\
\text { qualify } \\
\text { for...? }\end{array}$ & & \\
\hline 43 & $\begin{array}{l}\text { Then, ... I } \\
\text { do think } \\
\text { that we } \\
\text { ought to get } \\
\text { to work. }\end{array}$ & & \\
\hline 53 & $\begin{array}{l}\ldots \text { now } \ldots \text { I } \\
\text { will begin } \\
\ldots\end{array}$ & & \\
\hline 55 & & $\begin{array}{l}\text { Good. We } \\
\text { shall see. }\end{array}$ & \\
\hline 56 & $\begin{array}{l}\text { Now, miss, } \\
\text { would you } \\
\text { like to do a } \\
\text { little } \\
\text { arithmetic, } \\
\ldots\end{array}$ & & \\
\hline
\end{tabular}

\begin{tabular}{|c|c|c|c|}
\hline 59 & $\begin{array}{l}\text { Miss, I hope } \\
\text { you'll } \\
\text { pardon this } \\
\text { absurd } \\
\text { interruption } \\
\ldots\end{array}$ & & \\
\hline 61 & & & $\begin{array}{l}\text { But let's } \\
\text { return to } \\
\text { our } \\
\text { arithmeti } \\
\text { cal } \\
\text { knitting. }\end{array}$ \\
\hline 69 & $\begin{array}{l}\text { How much } \\
\text { are one and } \\
\text { one? }\end{array}$ & & \\
\hline 91 & & $\begin{array}{l}\text { At } \\
\text { addition } \\
\text { you are a } \\
\text { past } \\
\text { master. }\end{array}$ & \\
\hline 91 & $\begin{array}{l}\text { Now, let's } \\
\text { look at } \\
\text { subtraction. }\end{array}$ & & \\
\hline 103 & & $\begin{array}{l}\text { Let's try } \\
\text { to deduce } \\
\text { it together. }\end{array}$ & \\
\hline 103 & $\begin{array}{l}\text { Would you } \\
\text { like to } \\
\text { count? }\end{array}$ & & \\
\hline 111 & & $\begin{array}{l}\text { Stop there, } \\
\text { miss. }\end{array}$ & \\
\hline 111 & $\begin{array}{l}\text { Which } \\
\text { number is } \\
\text { larger? }\end{array}$ & & \\
\hline 117 & & $\begin{array}{l}\text { Let's not } \\
\text { go into } \\
\text { that. }\end{array}$ & \\
\hline 117 & $\begin{array}{l}\text { To facilitate } \\
\text { our work, } \\
\text { let's merely } \\
\text { suppose that } \\
\text { we have } \\
\text { only equal } \\
\text { numbers, } \\
\text { then the } \\
\text { bigger } \\
\text { numbers } \\
\text { will be } \\
\text { those that } \\
\text { have the }\end{array}$ & & \\
\hline
\end{tabular}


HUMANIKA Vol.25 No.1 (2018)

ISSN 1412-9418

Tersedia online di http://ejournal.undip.ac.id/index.php/humanika

\begin{tabular}{|c|c|c|c|}
\hline & most units. & & \\
\hline 119 & & $\begin{array}{l}\text { Let's } \\
\text { leave the } \\
\text { general } \\
\text { conclusion } \\
\text { for later. }\end{array}$ & \\
\hline 119 & $\begin{array}{l}\text { Which } \\
\text { number will } \\
\text { be larger, } \\
\text { the smaller } \\
\text { or the } \\
\text { larger? }\end{array}$ & & \\
\hline 129 & Look here. & & \\
\hline 179 & & $\begin{array}{l}\text { Let's try } \\
\text { another } \\
\text { approach }\end{array}$ & \\
\hline 180 & $\begin{array}{l}\text { Look here, } \\
\text { miss ... } \\
\text { You see ... }\end{array}$ & & \\
\hline 198 & & & $\begin{array}{l}\text { How } \\
\text { much, for } \\
\text { example, } \\
\text { are three } \\
\text { billion } \\
\text { seven } \\
\text { hundred } \\
\text { fifty-five } \\
\text { million } \\
\text { nine } \\
\text { hundred } \\
\text { ninety- } \\
\text { eight } \\
\text { thousand } \\
\text { two } \\
\text { hundred } \\
\text { fifty one, } \\
\text { multiplie } \\
\text { d by five } \\
\text { billion } \\
\text { one } \\
\text { hundred } \\
\text { sixty-two } \\
\text { million } \\
\text { three } \\
\text { hundred } \\
\text { and three } \\
\text { thousand } \\
\text { five } \\
\text { hundred } \\
\text { and } \\
\text { eight? } \\
\end{array}$ \\
\hline 204 & & That's & \\
\hline
\end{tabular}

\begin{tabular}{|c|c|c|c|}
\hline & & $\begin{array}{l}\text { pretty } \\
\text { good ... }\end{array}$ & \\
\hline 206 & & $\begin{array}{l}\text { Let's } \\
\text { leave it for } \\
\text { the } \\
\text { moment. }\end{array}$ & \\
\hline 206 & $\begin{array}{l}\text { Let's go on } \\
\text { to another } \\
\text { exercise ... }\end{array}$ & & \\
\hline 214 & & $\begin{array}{l}\text { I must } \\
\text { therefore } \\
\text { teach you, } \\
\text { if you } \\
\text { really do } \\
\text { insist on } \\
\text { attempting } \\
\text { the partial } \\
\text { doctorate } \\
\text {... }\end{array}$ & \\
\hline 217 & $\begin{array}{l}\text { I want you } \\
\text { to listen } \\
\text { now with } \\
\text { the greatest } \\
\text { possible } \\
\text { attention to } \\
\text { a lecture I } \\
\text { have } \\
\text { prepared ... }\end{array}$ & & \\
\hline 235 & $\begin{array}{l}\text {... And this, } \\
\text { too, is a } \\
\text { fundamental } \\
\text { principle, }\end{array}$ & & \\
\hline 243 & $\begin{array}{l}\text { What's the } \\
\text { matter? }\end{array}$ & & \\
\hline 245 & & & $\begin{array}{l}\text { Let us go } \\
\text { on ... }\end{array}$ \\
\hline 257 & $\begin{array}{l}\text { Thus, all the } \\
\text { words of all } \\
\text { the } \\
\text { languages } \\
\text {... }\end{array}$ & & \\
\hline 308 & $\begin{array}{l}\text { I don't get } \\
\text { the } \\
\text { difference. }\end{array}$ & & \\
\hline 311 & $\begin{array}{l}\text { Are you } \\
\text { listening? }\end{array}$ & & \\
\hline 316 & & & $\begin{array}{l}\text { Oh well } \\
\ldots \text { yes ... } \\
\text { yes ... go } \\
\text { on ... }\end{array}$ \\
\hline 334 & $\begin{array}{l}\text { Oh dear! } \\
\text { My teeth ... }\end{array}$ & & \\
\hline
\end{tabular}


It can be seen that the opening markers were used more to introduce new topics. The conversation also rarely used closing markers to end topics. However, it is interesting that there were some phrases used to close a topic and open another topic at the same time. To make the reader understand, the writer provides an extract of each category. The following extract gives an example of an opening marker.

Extract 3:

(89) $P$ : Perfect. Excellent. Seven and one?

(90) $Y \quad$ :Eight again. And sometimes nine.

(91) $P$ : Magnificent. You are magnificent. You are exquisite. I congratulate you warmly, miss. There's scarcely any point in going on. At addition you are a past master. Now, let's look at subtraction. Tell me, if you are not exhausted, how many are four minus three?

(92) $Y \quad$ :Four minus three? ... Four minus three?

(93) $P$ : Yes. I mean to say: subtract three from four.

Extract 3 gives a clear sign where one topic begins in a conversation. In line 91, it can be seen that the Professor says "now, let's look at subtraction" to give a clear opening marker to tell the Young Pupil that he is going to change the topic. The topic changes from 'addition' (sub topic of arithmetic) to 'subtraction' (another sub topic of arithmetic).

In the next extract, the writer provides the example of other category namely 'closing' marker. The marker is used as a sign where one topic ends.

Extract 4:

(103)P : Oh, certainly not, miss. It's not a matter of guessing, you've got to think it out. Let's try to deduce it together. Would you like to count?

(104) Y : Yes, Professor. One ... two ... uh ...

(105)P : You know how to count? How far can you count up to?

(106) Y : I can count up to ... to infinity.

(107)P : That's not possible, miss.

(108) $Y \quad$ : Well then, let's say to sixteen.

(109)P : That is enough. One must know one's limits. Count then, if you will, please.

(110) $Y$ : One ... two ... and after two, comes three ... then four ...

(111)P : Stop there, miss. Which number is larger? Three or four?

(112) $Y:$ Uh ... three or four? Which is the larger? The larger of three or four? In what sense larger?

In Extract 4 above, the Professor asks his pupil to do counting because he wants to know whether the Young Pupil 
can count or not. Counting is the sub-sub topic of arithmetic. Then, in line 111, he gives a closing marker 'stop there' to show the pupil that she must stop counting because he wants to discuss another topic namely 'small and large numbers' (another sub-sub topic of arithmetic).

After the example of 'opening' marker in Extract 3 and the example of 'closing' marker in Extract 4, the writer gives the example of the other category namely 'opening and closing' marker in Extract 5. In this category, the marker has two functions at the same time - to close one topic and to open another topic.

Extract 5:

(59) $P$ : Miss, I hope you'll pardon this absurd interruption ... Excuse this woman ... She is always afraid that I'll tire myself. She fusses over my health.

(60) $Y:$ Oh, that's quite all right, Professor. It shows that she's very devoted. She loves you very much. Good servants are rare.

(61) $P$ : She exaggerates. Her fears are stupid. But let's return to our arithmetical knitting.

(62) $Y$ : I'm following you, Professor.

(63) $P$ : Without leaving your seat!

(64) $Y$ : Like you, Professor.

(65) $P$ : Good. Let us arithmetize a little now.

(66) $Y$ :Yes, gladly, Professor.

In the extract above, there is an interruption made by the Maid. This makes the Professor apologize to his pupil (line 59). Because of the interruption, they talk about Marie for a while. Then, the topic changes from 'Marie' to 'arithmetic'. In line 61 , the Professor gives a sign to his pupil that he wants to stop talking about 'Marie' and to focus again on 'arithmetic' at the same time.

Another interesting finding related to the markers is that the Professor is the one who use the markers mostly. The pupil uses the markers to open and close topics before they start the lessons (in the introduction). When the lessons begin, the Professor becomes the dominant character. It shows that the position of the Professor as the teacher makes him have more power to control the conversation during the lessons. This is in line with what Esslin states that in The Lesson, "language is also shown as an instrument of power" (2001, p.146).

\section{Conclusion}

In conclusion, even in an absurd play where the structure is difficult to understand, there is a clear structure of the conversation. The main topics in The Lessons are Arithmetic, and Linguistics and Comparative Philology. The main topics could be analyzed from the topic 
boundary markers found in the conversation. There are 3 categories of topic boundary markers found in the conversation namely opening, closing, and opening and closing markers. The most common markers are the opening markers. In addition, the Professor is the character who uses most of the markers, especially during the lessons. It proves that as the teacher, the Professor has more power to control the conversation during the lessons. This is in relation with Esslin's statement that in The Lesson, "language is also shown as an instrument of power" (2001, p.146).

\section{References}

Brown, G and Yule, G. (1983). Discourse Analysis. Cambridge: Cambridge University Press.

Coulthard, M. (2014). An Introduction to Discourse Analysis (2 ${ }^{\text {nd }}$ Ed.). New York: Routledge
Esslin, M. (2001). The Theatre of the Absurd ( $3^{\text {rd }}$ Ed.). New York: Vintage Books

Jones, R. (2008). Turns, Topics and Tyranny: Conversation Analysis and Power in Alan Ayckbourn's Absurd Person Singular. Innervate, 1, 167-174. Retrieved from https://www.nottingham.ac.uk/english/ documents/innervate/0809/0809jones2dramaticdiscourse.pdf

McCarthy, M. (1991). Discourse Analysis for Language Teachers. Cambridge: Cambridge University Press

Stenstrom, A. (2014). An Introduction to Spoken Interaction. New York: Routledge.

Wulandari, A. (2001). Topic Shift and Topic Shift Markers Used by Male and Female Students of Petra Christian University at the Boarding House (Unpublished Thesis). Retrieved from http://dewey.petra.ac.id/catalog/ft_d etail.php?knokat=140

Press. 